\title{
Study of risk factors and tumor markers in ovarian malignancy in western part of Odisha: a prospective observational study
}

\author{
Hemanta Kumar Pradhan ${ }^{1 *}$, Pratibha Singh $^{2}$, M. S. Ravikumar ${ }^{3}$, Meenakshi Gothwal ${ }^{2}$
}

\author{
${ }^{1}$ Department of Obstetrics and Gynecology, KIMS and RF, Amalapurum, Andhra Pradesh, India \\ ${ }^{2}$ Department of Obstetrics and Gynecology, AIIMS, Jodhpur, Rajasthan, India \\ ${ }^{3}$ Department of Community Medicine, KIMS and RF, Amalapurum, Andhra Pradesh, India
}

Received: 07 February 2018

Accepted: 07 March 2018

\author{
*Correspondence: \\ Dr. Hemanta Kumar Pradhan, \\ E-mail: drhemantakumar@gmail.com
}

Copyright: ( $)$ the author(s), publisher and licensee Medip Academy. This is an open-access article distributed under the terms of the Creative Commons Attribution Non-Commercial License, which permits unrestricted non-commercial use, distribution, and reproduction in any medium, provided the original work is properly cited.

\begin{abstract}
Background: Ovarian cancer represents one of the most frequently seen malignancies in women and it is the fifth most common cause of cancer-related death in women. The aim of the study to determine the risk factors leading to ovarian cancer in western part of Odisha, India and show the tumour markers in this population.

Methods: This is a prospective observational study included 240 ovarian masses diagnosed at Department of Obstetrics and Gynaecology, V. S. S. Medical College, Burla, Sambalpur over 3 years based on preoperative clinical, biochemical (tumour markers) and imaging study and confirm through post-operative histopathology reports.

Results: Surface epithelial tumours $(68.33 \%)$ followed by germ cell tumours $(30.83 \%)$ are the most common ovarian tumour. Incidence of ovarian cancer is $73.58 \%$ in $\leq 50$ years of age group and more number of cases $(16.65 \%)$ also found in younger age $(\leq 30$ year). Overall number of ovarian cancer cases rising. Bilateral tubal ligation is not a protective factor for ovarian cancer ( $p$ value $>0.05$ ) and consumption of alcohol and tobacco is not increase risk for ovarian cancer. Most of ovarian tumour commonly present with vague abdominal pain (75.83\%) followed by mass per abdomen (55\%). Ascites mainly a presentation of malignant tumour seen in $46(63.88 \%)$ cases. CA125 is the frequently detected tumour markers and all of the tumour markers were significantly within normal limit.

Conclusions: Ovarian neoplasia is one of the most common and lethal malignancy in female reproductive tract. Though it is a disease of older age but now a day more no of cases also seen in younger age group. Since most of the ovarian cancer remain asymptomatic for long period so measure should be taken for early diagnosis for best outcome. So, assessment of each regions statistical information reflecting its own profile may be important for estimation of risk for development of ovarian cancer and so useful for early preventive measure before progress to advance stage where prognosis is worst. So, relationship between the profiles of patients and types of ovarian neoplasms may give an idea about the risk factors of the disease in its region. Additionally, distribution of tumour markers might be considered for the dis-criminating of the benign or malign characters of the ovarian neoplasia.
\end{abstract}

Keywords: Fetal malignancy distress, Hypertension ovarian in pregnancy, Risk factors stillbirths, Tumour markers

\section{INTRODUCTION}

Ovarian cancer represents one of the most frequently seen malignancies in women and it is the fifth most common cause of cancer-related death in women. ${ }^{1}$ It is considered to be the most lethal malignancy of the female reproductive system, largely because it is usually diagnosed at an advanced stage. ${ }^{2}$ The total number of ovarian cancer cases worldwide has been estimated to be 1, 92,000 per year in 2000 and representing $4 \%$ of all 
cancers in women and the sixth leading site of malignancy. ${ }^{3}$ Indian cancer registry data project ovary as a common site of cancer in women, comprising up to $8.7 \%$ of cancers in different parts of the country. ${ }^{4}$ Histopathology report of ovarian neoplasm exhibits wide spectrum of variation. Distribution of the different ovarian tumours has been widely studied in western countries. However, no such study is available in eastern part of India.

The risk factors of ovarian cancer are though multifactorial but menstrual reproductive events including parity, menarche and menopause status, life style habits and genetic may have a role.

With increasing life expectancy, there is increase in incidence of ovarian neoplasm making it a public health problem. Therefore, an understanding of epidemiologic and genetic factors of ovarian cancer is important information for public health and health care planning for prevention, screening, early diagnosis and control of disease.

In this scenario we have studied the risk factor, clinical presentation and histological pattern and tumour markers of patients with ovarian neoplasm in a tertiary care hospital in western Odisha in Eastern part of India.

\section{METHODS}

This cross-sectional study (Observational Research Method) was carried out at Department of Obstetrics and Gynaecology, V.S.S. Medical College, Burla, Sambalpur a tertiary care hospital in western part of Odisha, India over a period of 3 year. Necessary clearances and permissions were obtained from the Institutional Ethics Committee for Human Research before starting the study. After obtaining a written informed consent, all female patients were enquired about their leading symptoms such as pain with duration, type and localization, abdominal swelling, anorexia, weight loss; urinary symptoms associated with frequency, urgency.

Any abnormal vaginal discharge or menstrual irregularities were also noted. General physical examination of patients with particular attention to abdomen was done. Per vaginal and per rectal examination was done in each case. Inspection, palpation, percussion and auscultation finding were noted. Size, consistency, mobility of any mass present is elicited. Shifting dullness and fluid thrill were also done for ascites. Provisional diagnosis was made based on signs, symptoms and examination.

Routine haematological and biochemical investigation done for surgical fitness and imaging study including ultrasound, CT or MRI done as required for additional information to detect stage of disease. Serum tumour markers including CA-125, CEA, HCG, and AFP of the patients were also sending. The cut-off values were 35
$\mathrm{U} / \mathrm{mL}$ for CA-125, 2.5 for CEA, 5 for hCG and 6 for AFP. ${ }^{5}$ Serum CA-125 values were determined as normal lower than $35 \mathrm{U} / \mathrm{mL}$ and higher more than $35 \mathrm{U} / \mathrm{mL}$. Other tumour markers were similarly evaluated normal or higher according to the cut-off values.

The average time interval between admission and laparotomy was 1-2 weeks and more in some cases. The cause of delay was mainly due to anaemia. For emergency cases who presented with feature of acute abdomen the time interval was 6-24 hours.

Final diagnosis was confirmed on histopathology and ovarian tumours were classified according to histological classification of World Health Organization (WHO). ${ }^{6}$ All the data was entered into a Microsoft Excel Sheet and analysed by using Stat Disc free software version 13.0.1

\section{RESULTS}

The present study was undertaken in the department of obstetrics and gynecology, V.S.S. Medical College, Burla, Sambalpur, a tertiary care centre in western part of Odisha. It was done in a study population of 240 patients. The cases of our study group were operated for ovarian tumor either electively or in emergency over a period of 3 years.

Among the 240 cases of ovarian tumour, the median age at presentation was 34 years. In our study (Table 1) majority of the tumors are in 41-50years (29.1\%). Average age for benign tumor is $31-40$ years $(28.57 \%)$ whereas that for malignant tumor is $41-50$ years $(40.27 \%)$. Table 1 also shows that beyond 60 years incidence of ovarian tumors decreases. This may be due to decrease life expectancy and less accesses to medical treatment in old age in developing country.

Table 1: Age distribution in ovarian tumors.

\begin{tabular}{|lllllll|}
\hline $\begin{array}{l}\text { Age } \\
\text { groups } \\
\text { (years) }\end{array}$ & $\begin{array}{l}\text { No } \\
\text { of } \\
\text { cases }\end{array}$ & $\begin{array}{l}\text { \% of } \\
\text { total } \\
\text { cases }\end{array}$ & $\begin{array}{l}\text { Benign } \\
\text { cases }\end{array}$ & \multicolumn{3}{l|}{ Malignant } \\
\hline$<20$ & 20 & 8.3 & 18 & 10.71 & 02 & 02.77 \\
\hline $21-30$ & 44 & 18.3 & 34 & 20.23 & 10 & 13.88 \\
\hline $31-40$ & 60 & 25 & 48 & 28.57 & 12 & 16.66 \\
\hline $41-50$ & 70 & 29.1 & 41 & 24.40 & 29 & 40.27 \\
\hline $51-60$ & 36 & 15 & 21 & 12.50 & 15 & 20.83 \\
\hline$>60$ & 10 & 4.1 & 06 & 03.57 & 04 & 05.55 \\
\hline
\end{tabular}

Table 2 show the relationship between parity with ovarian tumors. It is found that more number of ovarian tumor seen in women with two issues $(27.5 \%)$. This may be due to seen that as parity increases incidence of ovarian malignancy decreases.

Maximum incidence of ovarian neoplasia seen in nulliparous women. (27.77\%). This may be explained by multiple times injury to ovary by repeated ovulation in case of infertility. 
Table 2: Relationship between parity with ovarian tumors.

\begin{tabular}{|lllllll|}
\hline & $\begin{array}{l}\text { Total } \\
\text { no of }\end{array}$ & $\begin{array}{r}\text { \% of } \\
\text { total }\end{array}$ & \multicolumn{2}{l}{ Benign } & \multicolumn{2}{l}{ Malignant } \\
Parity & cases & cases & No. & No. & $\%$ \\
\hline P0 & 34 & 14.16 & 14 & 08.33 & 20 & 27.77 \\
\hline P1 & 42 & 17.50 & 28 & 16.66 & 14 & 19.44 \\
\hline P2 & 66 & 27.50 & 52 & 30.95 & 14 & 19.44 \\
\hline P3 & 48 & 20.00 & 36 & 21.42 & 12 & 16.66 \\
\hline P4 & 32 & 13.66 & 24 & 14.28 & 08 & 11.11 \\
\hline >P4 & 18 & 07.50 & 14 & 08.33 & 04 & 05.55 \\
\hline
\end{tabular}

Table 3 shows that the relationship between place of living with ovarian tumors. Incidence of ovarian tumor is more common in people living rural area $(21.66 \%)$ than urban area $(8.33 \%)$. This may be due to less approach for medical care as compare to urban population.

Table 3: Relationship between places of living with ovarian tumor.

\begin{tabular}{|lllrrrrr|}
\hline & $\begin{array}{l}\text { No. } \\
\text { Type }\end{array}$ & $\begin{array}{l}\text { \% of } \\
\text { total }\end{array}$ & \multicolumn{2}{c}{ Benign } & \multicolumn{3}{c|}{ Malignant } \\
& cases & cases & No. & $\%$ & No. & $\%$ \\
\hline Rural & 156 & 65.00 & 104 & 61.90 & 52 & 72.22 \\
\hline Urban & 84 & 35.00 & 64 & 38.10 & 20 & 27.78 \\
\hline
\end{tabular}

Table 4, 5 and 6 shows the relationship between tobacco chewing/smoking, alcohol and BTL with ovarian malignancy. It shows that ovarian cancer is not common in women addicted or habituated to tobacco or alcohol. This is also similar with tubal ligation.
Incidence of ovarian tumor is more common in women without BTL (26.66\%) than with BTL $(3.33 \%)$.

Table 4: Relationship between tobacco (chewing/smoking) with ovarian tumors.

\begin{tabular}{|l|llllll|}
\hline Type & $\begin{array}{l}\text { No. } \\
\text { of } \\
\text { cases }\end{array}$ & $\begin{array}{l}\text { total } \\
\text { cases }\end{array}$ & No. & \multicolumn{2}{l}{ Benign } & \multicolumn{3}{l|}{ Nalignant } & $\%$ \\
\hline Tobacco & 86 & 35.83 & 70 & 41.66 & 18 & 25.00 \\
\hline $\begin{array}{l}\text { Non- } \\
\text { tobacco }\end{array}$ & 154 & 64.17 & 98 & 58.34 & 54 & 75.00 \\
\hline
\end{tabular}

Table 5: Relationship between alcohol with ovarian tumor.

\begin{tabular}{|lllllll|}
\hline Type & $\begin{array}{l}\text { No. } \\
\text { of } \\
\text { cases }\end{array}$ & $\begin{array}{l}\text { \% of } \\
\text { total } \\
\text { cases }\end{array}$ & \multicolumn{2}{l}{ Nonign } & $\%$ & \multicolumn{2}{l|}{ No. } & $\%$ \\
\hline Alcoholic & 42 & 17.50 & 32 & 19.04 & 10 & 13.88 \\
\hline $\begin{array}{l}\text { Non- } \\
\text { alcoholic }\end{array}$ & 198 & 82.50 & 136 & 80.95 & 62 & 86.11 \\
\hline
\end{tabular}

Table 7 shows the different presentation of ovarian tumors. Pain is the commonest complaint present in 194 $(80.83 \%)$ cases, among which $182(75.83 \%)$ with vague pain (discomfort) whereas $12(5 \%)$ cases are having severe pain abdomen. Lump in abdomen is marked in 132 $(55 \%)$ cases out of which $80(47.61 \%)$ cases are benign and $52(72.22 \%)$ cases are malignant. Menstrual irregularities are present in $36(15 \%)$ cases. Anemia is another common finding present in $172(71.66 \%)$ cases. Ascites mainly a presentation of malignant tumor seen in $46(63.88 \%)$ cases. Anorexia and weight loss are another common presentation in malignant tumor.

Table 6: Relationship between $\mathrm{B} / \mathrm{L}$ tubal ligation with ovarian tumor.

\begin{tabular}{|llllllll|}
\hline \multirow{2}{*}{ Type } & No. of cases & $\%$ of total cases & Benign & \multicolumn{3}{c}{ Malignant } & \multicolumn{2}{c|}{ P value } \\
\hline BTL done & 76 & 31.66 & 68 & 40.47 & 08 & 11.11 & 0.060 \\
\hline BTL not done & 164 & 68.34 & 100 & 59.53 & 64 & 88.89 & 0.004 \\
\hline
\end{tabular}

Table 7: Symptom analysis in ovarian tumors.

\begin{tabular}{|lllllll|}
\hline Symptoms and signs & No. of cases & $\%$ & \multicolumn{3}{c|}{ Benign } & \multicolumn{3}{c|}{ Malignant } \\
\hline Vague pain in abdomen & 182 & 75.83 & 118 & 70.23 & 64 & 88.88 \\
\hline Severe pain in abdomen & 12 & 5 & 10 & 05.95 & 02 & 02.77 \\
\hline Lump in abdomen & 132 & 55 & 80 & 47.61 & 52 & 72.22 \\
\hline Menstrual irregularity & 36 & 15 & 24 & 14.28 & 12 & 16.66 \\
\hline Urinary complaint & 24 & 10 & 10 & 05.95 & 14 & 19.44 \\
\hline Constipation & 18 & 7.5 & 06 & 03.57 & 12 & 16.66 \\
\hline Pedal edema & 44 & 18.33 & 16 & 09.52 & 28 & 38.88 \\
\hline Anemia (<11gm\%) & 172 & 71.66 & 118 & 70.23 & 54 & 75.00 \\
\hline Weakness & 118 & 49.16 & 54 & 45.76 & 64 & 88.88 \\
\hline Anorexia & 86 & 35.83 & 24 & 14.28 & 62 & 86.11 \\
\hline Ascites & 48 & 20 & 02 & 01.90 & 46 & 63.88 \\
\hline Weight loss & 36 & 15 & 06 & 03.57 & 30 & 41.66 \\
\hline Pregnancy & 04 & 1.66 & 03 & 01.78 & 01 & 01.38 \\
\hline Infertility & 16 & 6.66 & 04 & 02.38 & 12 & 16.66 \\
\hline
\end{tabular}


Table 8: Study of tumor markers in ovarian tumor.

\begin{tabular}{|c|c|c|c|c|c|c|}
\hline & \multirow{2}{*}{ Types of tumor } & \multicolumn{5}{|c|}{ Tumor marker positive } \\
\hline & & CA125 & hCG & AFP & LDH & CEA \\
\hline \multirow{9}{*}{ Surface epithelial } & Serous (136) & & & & & \\
\hline & Benign (106) & 20 & - & - & - & 02 \\
\hline & Malignant (30) & 28 & - & - & - & 04 \\
\hline & Mucinous (20) & & & & & \\
\hline & Benign (12) & 01 & - & - & - & 02 \\
\hline & Malignant (08) & 02 & - & - & - & 06 \\
\hline & *Endometriod (04) & 04 & - & - & - & - \\
\hline & $*$ Clear cell $(02)$ & 02 & - & - & - & - \\
\hline & \#Transitional (01) & 01 & - & - & - & - \\
\hline \multirow{8}{*}{ Germ cell tumor } & Teratoma (56) & & & & & \\
\hline & Benign (44) & 08 & & & & \\
\hline & Malignant (12) & 02 & 1 & 4 & 6 & \\
\hline & *\#Mixed germ cell (06) & 01 & & 1 & & \\
\hline & Dysgerminoma (12) & - & 03 & 01 & 05 & \\
\hline & Yolk sac & - & - & - & - & - \\
\hline & Embryonal & - & - & - & - & - \\
\hline & Choriocarcinoma & - & - & - & - & - \\
\hline \multirow{4}{*}{ Sex cord stromal } & Granulosa & - & - & - & - & - \\
\hline & Sertoli Ledig & - & - & - & - & - \\
\hline & \#Fibroma (02) & - & - & - & - & - \\
\hline & Lipid cell & - & - & - & - & - \\
\hline \multirow{2}{*}{ Metastatic } & *Krukenberg (01) & - & - & - & - & 01 \\
\hline & Others & - & - & - & - & - \\
\hline
\end{tabular}

\#benign; *malignant; \#*both benign and malignant

Table 9: General classification of ovarian tumors (total 240).

\begin{tabular}{|c|c|c|c|c|c|}
\hline Type of tumors & Histopathology & No. of cases & $\%$ & Bilateral & $\%$ \\
\hline \multirow{11}{*}{ Surface epithelial } & Serous & & & & \\
\hline & Total & 136 & 56.66 & 36 & 26.47 \\
\hline & Benign & 106 & 44.16 & 16 & 15.09 \\
\hline & Malignant & 30 & 12.50 & 20 & 66.66 \\
\hline & Mucinous & & & & \\
\hline & Total & 20 & 8.33 & 06 & 30 \\
\hline & Benign & 12 & 5 & 02 & 16.66 \\
\hline & Malignant & 08 & 3.33 & 04 & 50 \\
\hline & *Endometrioid & 04 & 1.66 & 02 & 50 \\
\hline & *Clear cell & 02 & 0.83 & 01 & 50 \\
\hline & \#Transitional & 01 & 0.41 & 00 & 00 \\
\hline \multirow{9}{*}{ Germ cell } & Teratoma & & & & \\
\hline & Total & 56 & 23.33 & 10 & 17.85 \\
\hline & Benign & 44 & 18.33 & 04 & 9.09 \\
\hline & Malignant & 12 & 5 & 06 & 50 \\
\hline & \#*Mixed germ cell & $06(3+3)$ & 2.5 & 03 & 50 \\
\hline & Dysgermina & 12 & 5 & 02 & 16.66 \\
\hline & Yolk sac tumor & 00 & & 00 & \\
\hline & Embryonal ca & 00 & & 00 & \\
\hline & Choriocarcinoma & 00 & & 00 & \\
\hline \multirow{4}{*}{ Sex cord stromal } & Granulosa & 00 & & 00 & \\
\hline & Sertoli-ledig & 00 & & 00 & \\
\hline & \#Fibroma/thecoma & 02 & 0.83 & 00 & 00 \\
\hline & Lipid cell tumour & 00 & & 00 & \\
\hline Others & Metastatic & 01 & 0.41 & 01 & 100 \\
\hline
\end{tabular}

\#benign; *malignant; \#*both benign and malignant 
Table 8 depicts estimation of various tumors markers in evaluation of ovarian tumors. CA-125 is the commonest tumors markers seen $(28.75 \%)$ followed by CEA $(5.83 \%)$ and LDH $(4.58 \%)$. CA-125 commonly raised in nonmucinous serous tumor of ovary. Table 9 depicts different types of tumors according to histopathological reports. Out of 240 cases, $18(68.33 \%)$ are benign and $72(31.66 \%)$ are malignant. Surface epithelial tumors $(67.91 \%)$ are the commonest variety of ovarian tumors followed by germ cell tumors (30.83\%). Serous cystadenoma is the commonest benign (44.16\%) and serous cystadenocarcinoma $(12.5 \%)$ is the commonest malignant tumors. Malignant tumors mostly showed B/L involvement.

Table 10: Relationship between age with stage of ovarian malignancy.

\begin{tabular}{|lccccccc|}
\hline $\begin{array}{l}\text { Stage } \\
\text { /age }\end{array}$ & $<21$ & $\begin{array}{l}21- \\
30\end{array}$ & $\begin{array}{l}31- \\
40\end{array}$ & $\begin{array}{l}41- \\
50\end{array}$ & $\begin{array}{l}51- \\
60\end{array}$ & $>60$ & $\%$ \\
\hline $\begin{array}{l}\text { Stage } \\
1\end{array}$ & 02 & 03 & 04 & 04 & 03 & 00 & 22.22 \\
\hline $\begin{array}{l}\text { Stage } \\
2\end{array}$ & 00 & 01 & 02 & 06 & 03 & 01 & 18.05 \\
\hline $\begin{array}{l}\text { Stage } \\
3\end{array}$ & 00 & 00 & 02 & 10 & 04 & 01 & 23.61 \\
\hline $\begin{array}{l}\text { Stage } \\
4\end{array}$ & 00 & 00 & 04 & 14 & 06 & 02 & 36.11 \\
\hline
\end{tabular}

Table 10 shows the distribution of FIGO stage in ovarian cancer. Most of the cancer in advanced stage i.e. in FIGO stage $1,2,3$ and 4 are $22.22 \%, 18.05 \%, 23.61 \%$ and $36.11 \%$ respectively.

\section{DISCUSSION}

Ovarian tumours are fairly common in gynecological practice. In our present study ovarian tumour constitutes $2.94 \%$ of all gynecological admissions. Benign neoplasm was observed in $70 \%$ and malignant tumours in $30 \%$ cases. The overall incidence of benign tumour was more than malignant tumours which was in accordance with most of the authors as given below. A similar study by Gupta et al reported $72.9 \%$ benign and $22.9 \%$ malignant tumours. ${ }^{7}$ These findings are in close approximation to those observed in the study conducted by Khan and Luqman that has shown $76 \%$ of ovarian tumours to be benign. ${ }^{8}$ Other similar study conducted by Rettenmaier et al has also reported a higher proportion (nearly 20\%) of borderline ovarian tumors. ${ }^{9}$ This difference may be due to variation in sample size and/or involvement of environmental, socio-economical and genetic factors in their causation.

In the present study the median age of presentation of ovarian tumours were 32 years while for malignant lesions were 45 years. Benign tumours were diagnosed mostly in patients between 21-40 years of age where as malignant lesion between 41-60 years. Similar studies by other investigators have highlighted that most ovarian tumours $(47.2 \%)$ are seen between $21-40$ years, whereas most malignant tumours have been noted (73.1\%) above 40 years. ${ }^{10}$ In another study from Iran, the median age for malignant lesions was reported to be 49 years. A higher median age of 60-65 years for malignant lesions has been reported from the western countries and from southern and western part of India. ${ }^{1-13}$ With the increase in absolute numbers of older women in western country and some developed part of India due to increase in life expectancy, the effect of ovarian cancer for this age group is expected to be increased.

However, few cases of malignant ovarian tumours were also found in the 21-40-year group the indication towards an earlier presentation of malignant lesions in the present study warrants prompt and thorough investigation of any vague abdominal complaint in women in middle age group.

In this present study maximum number of ovarian neoplasia seen in nulliparous women $(8.33 \%)$. It is also seen that as parity increases incidence of ovarian malignancy decreases which is also described by many authors Riman et al and Danforth et al respectively. ${ }^{14-15}$

Incidence of ovarian tumor is more common in people living rural area $(21.66 \%)$ than urban area $(8.33 \%)$ in the present study. This may be due to the people staying in urban location for better access for medical care.

Table 4 shows that the relationship between habituation (tobacco chewing/smoking and/or alcohol) with ovarian tumours. Incidence of ovarian tumour is more common in women without bad habit $(22.5 \%)$ than those with bad habit $(7.5 \%)$. Although many studies in the literature claimed that cigarette smoking was associated with an increased risk for ovarian cancers, especially mucinous epithelial ovarian cancer. ${ }^{16-18}$ Goodman and Tung reported that active tobacco smoking was not a risk factor for invasive ovarian cancer. ${ }^{19}$ In a recent large population study, epithelial ovarian cancer did not observe an association with smoking. ${ }^{20}$ Present results confirm that to tobacco smoking/chewing may not increase the risk of ovarian cancer. However, this study was only observational study but not a randomized control trial for assessment of tobacco in relation with ovarian cancer.

A case control study conducted by Nandakumar et al in Bangalore observed that tubectomy reduces the risk of ovarian cancer but the present study contradicts the result showing incidence of ovarian tumor is more common in women without BTL $(26.66 \%)$ than with BTL $(3.33 \%) .{ }^{21}$ This may be due to very low rate of sterilization operation in rural area also may be due to less no of case.

No symptom complex is diagnostic of ovarian tumors. Most of the early cases are asymptomatic. Differentiating a benign neoplasm from a malignant one sometimes challenging for gynecologist. A complete list of clinical features associated with ovarian tumors in this series is 
given in the Table 6. Pain is the commonest complaint present in $194(80.83 \%)$ cases, among which 182 $(75.83 \%)$ with vague pain (discomfort) whereas $12(5 \%)$ cases are having severe pain abdomen in cases of ovarian tumors studied in this series. Vague pain with bloating is more common in malignant tumors $(60 \%)$ where as severe pain appears to be same in both benign and malignant tumors $(2.5 \%)$. Most of the cause for severe pain in benign mass due to torsion or haemorrhagic cyst of ovary. Lump in abdomen is marked in $132(55 \%)$ cases out of which $46(19.17 \%)$ cases are benign and 86 $(35.83 \%)$ cases are malignant. Similar study performed by Yogambal et al reported pain abdomen $(66.92 \%)$ and mass in abdomen $(28.11 \%)$ as the commonest presenting symptom. $^{22}$ Menstrual irregularities are present in $36(15 \%)$ cases. Anaemia is another common finding present in $172(71.66 \%)$ cases. Ascites mainly a presentation of malignant tumours seen in $48(19.16 \%)$ cases. Anorexia and weight loss are another common presentation in malignant tumours as well.

In the present study estimation of various tumours markers done in evaluation of ovarian tumours. CA125 is the commonest tumours markers seen $(28.75 \%)$ followed by CEA $(5.83 \%)$ and $\mathrm{LDH}(4.58 \%)$. Different authors also described CA 125 mainly raised in serous tumour and CEA raised in mucinous tumour of ovary. ${ }^{23-27}$

Ovarian tumour was classified by the World Health Organization (WHO) is based on the cell type of the normal ovary. In the present study out of 240 cases, $168(68.33 \%)$ are benign and $72(31.66 \%)$ are malignant. Surface epithelial tumours $(67.91 \%)$ are the commonest variety of ovarian tumours. Serous cystadenoma is the commonest benign $(44.16 \%)$ and serous cystadenocarcinoma $(12.5 \%)$ is the commonest malignant tumour. Similar study performed by different authors show surface epithelial tumours are the commonest and these tumours comprise $48.8 \%$ and $63.5 \%$ of all ovarian tumours in two different studies. ${ }^{7,28}$

Germ cell tumour was the second most common group of tumours in the present study $(30.83 \%)$. The proportion of germ cell tumours varied in other studies from 23.9 to $42.2 \%{ }^{7,10}$ Mature teratoma was the commonest benign germ cell tumour in the present study $(23.33 \%)$. In the present study, we encountered 27 malignant germ cell tumours with both dysgerminoma and malignant teratoma of same incidence. (44.44\%, $5 \%$ of all ovarian tumours) with variation of increase no of immature teratoma when compare with different study. ${ }^{29}$ This variation was may be due to different geographical region or may be due to less no cases. The distribution of sex cord stromal tumours and metastatic tumours in the present study was rare and this may be due to less no of case or different geographical distribution.

Malignant ovarian tumour mostly showed bilateral involvement and the bilateral involvement varies with histologic subtype. In the present study, the most common ovarian tumour with bilateral involvement was malignant serous tumour $(66.66 \%)$ followed by $50 \%$ of malignant mucinous tumours excluding the metastatic krukenberg tumour (one in number) which was nearly in accordance with data collected by the Surveillance Epidemiology and End Results (SEER) diagnosed with a borderline or malignant epithelial ovarian tumour were found to be bilateral in $57.5 \%$ of cases.

In ovarian tumours prognosis is strongly associated with the stage at diagnosis though the histologic grade may also play role particularly in predicting recurrence. ${ }^{30}$ Many ovarian cancer are usually asymptomatic and have advanced disease at the time of diagnosis in more than two third of cases because of delay between onset of symptoms and diagnosis. ${ }^{31}$ In the present study distribution of ovarian cancer shows $22.22 \%, 18.05 \%$, $23.61 \%$ and $36.11 \%$ in FIGO stage $1,2,3$ and 4 respectively which indicates that many tumors are found in advanced stage which is also described by many authors as given below.

Basu et al reported $80 \%$ patients in stage III/IV at diagnosis but Saini et al described $20.8 \%$ cases were in stage II, $47.85 \%$ in stage III and $16.56 \%$ in stage IV. ${ }^{32,33}$ In a study by Mondal et al had $20 \%$ cases in stage II and $60 \%$ in stage III while Doufekas et al reported $60 \%$ cases were diagnosed in stage III and IV. ${ }^{34,35}$

\section{CONCLUSION}

Ovarian neoplasia is one of the most common and lethal malignancy in female reproductive tract in older age group but now a days more no. of cases also seen in younger age group. As life expectancy increases also easy accessibility of medical facility incidence of ovarian cancer increases. Since most of the ovarian cancer remain asymptomatic for prolong period so measure should be taken for early diagnosis for better outcome. So, assessment of each regions statistical information reflecting its own profile may be important for calculation of risk for development of ovarian cancer and so helpful for preventive measure. The relationship between the profiles of patients and types of ovarian neoplasms may give an idea about the risk factors of the disease in its region. Additionally, distribution of tumor markers might be considered for the discriminating of the benign or malign characters of the ovarian neoplasia.

\section{ACKNOWLEDGMENTS}

Authors would like to thank Dean (principal) V.S.S. Medical College for allowing us to use hospital data for preparation of this manuscript.

\section{Funding: No funding sources Conflict of interest: None declared}

Ethical approval: The study was approved by the Institutional Ethics Committee 


\section{REFERENCES}

1. Jemal A, Siegel R, Ward E, Murray T, Xu J, Thun MJ. Cancer statistics 2007. CA Cancer J Clin. 2007;57(1):43-66.

2. Wang K, Li Y, Jiang YZ, Dai CF, Patankar MS, Song JS, et al. An endogenous aryl hydrocarbon receptor ligand inhibits proliferation and migration of human ovarian cancer cells. Cancer Lett. 2013;340(1):63-71.

3. Parkin DM, Bray F, Ferlay J, Pisani P. Estimating the world cancer burden: GLOBOCAN 2000. Int J Cancer. 2001;94:153-6.

4. Murthy NS, Shalini S, Suman G, Pruthvish S, Mathew A. Changing trends in incidence of ovarian cancer: the Indian scenario. Asian Pac J Cancer Prev. 2009; 10:1025-30.

5. Sturgeon CM, Lai LC, Duffy MJ. Serum tumour markers: how to order and interpret them. BMJ. 2009;339:b3527.

6. Scully RE. Histological classification of ovarian tumours. In: Scully RE, editor. Ovarian Tumors. $2^{\text {nd }}$ ed. Berlin: Springer-Verlag; 1999:100-120.

7. Gupta N, Bisht D, Agarwal AK, Sharma VK. Retrospective and prospective study of ovarian tumours and tumour-like lesions. Indian J Pathol Microbiol. 2007;50:525-7.

8. Khan AA, Luqman M, Jamal S, Mamoon N, Mushtaq S. Clinico pathological analysis of Ovaria tumors. Pak J Pathol. 2005;16:28-32.

9. Rettenmaier MA, Lopez K, Abaid LN, Brown JV, Micha JP, Goldstein BH. Borderline ovarian tumors and extended patient follow-up: An individual institution's experience. J Surg Oncol. 2010;101:18 21.

10. Jha R, Karki S. Histological pattern of ovarian tumors and their age distribution. Nepal Med Coll J. 2008;10:81-5.

11. Murthy NS, Shalini S, Suman G, Pruthvish S, Mathew A. Changing trends in incidence of ovarian cancer - the Indian scenario. Asian Pac J Cancer Prev 2009; 10:1025-30.

12. Yancik R. Ovarian cancer. Age contrasts in incidence, histology, disease stage at diagnosis, and mortality. Cancer. 1993;71(2):517-23.

13. Quirk JT, Natarajan N. Ovarian cancer incidence in the United States, 1992-99. Gynecol Oncol. 2005;97:519-23.

14. Riman T, Dickman PW, Nisson S. Risk factors for invasive epithelial ovarian cancer: results from Swedish sasesontrol study. Am J Epidemiol. 2002;156:363-73.

15. Danforth KN, Tworoger SS, Hecht JL. Prospective study of postmenopausal hormone use and ovarian cancer risk. Br J Cancer. 2007;96:151-6.

16. Marchbanks PA, Wilson H, Bastos E. Cigarette smoking and epithelial ovarian cancer by histologic type. Obstet Gynecol. 2000;95:255-60.

17. Modugno F, Ness RB, Cottreau CM. Cigarette smoking and the risk of mucinous and nonmucinous epithelial ovarian cancer. Epidemiol. 2002;13:46771.

18. Zhang Y, Coogan PF, Palmer JR. Cigarette smoking and increased risk of mucinous epithelial ovarian cancer. Am J Epidemiol. 2004;159:133-9.

19. Goodman MT, Tung KH. Active and passive tobacco smoking and the risk of borderline and invasive ovarian cancer (United States). Cancer Causes Control. 2003;14:569-77.

20. Tworoger SS, Gertig DM, Gates MA. Caffeine, alcohol, smoking, and the risk of incident epithelial ovarian cancer. Cancer. 2008;112:1169-77.

21. Nandakumar A, Anantha N, Dhar M. A case-control investigation on cancer of the ovary in Bangalore, India. Int J Cancer. 1995;63:361-5.

22. Yogambal M, Arunalatha P, Chandramouleeswari K, Palaniappan V. Ovarian tumours: incidence and distribution in a tertiary referral center in South India. IOSR. 2014;13(2):74-80.

23. Bast RC Jr, Klug TL, St John E. A radioimmunoassay using a monoclonal antibody to monitor the course of epithelial ovarian cancer. N Engl J Med. 1983;309:883Y887.

24. Duffy MJ, Bonfrer JM, Kulpa J. CA125 in ovarian cancer: European group on tumor markers guidelines for clinical use. Int $\mathbf{J}$ Gynecol Cancer. 2005;15:679Y691.

25. Kelly PJ, Archbold P, Price JH. Serum CA19.9 levels are commonly elevated in primary ovarian mucinous tumours but cannot be used to predict the histological subtype. J Clin Pathol. 2010;63:169Y173.

26. Sturgeon CM, Duffy MJ, Stenman UH. National Academy of Clinical Biochemistry laboratory medicine practice guidelines for use of tumor markers in testicular, prostate, colorectal, breast, and ovarian cancers. Clin Chem. 2008;54:e11Ye79.

27. Høgdall EV, Christensen L, Kjaer SK. Protein expression levels of carcinoembryonic antigen (CEA) in Danish ovarian cancer patients: from the Danish 'MALOVA' ovarian cancer study. Pathol. 2008;40:487Y492.

28. Ahmad Z, Kayani N, Hasan SH, Muzaffar S, Gill MS. Histological pattern of ovarian neoplasma. J Pak Med Assoc. 2000;50:416-9.

29. Topuz S, Iyibozkurt AC, Akhan SE, Keskin N, Yavuz E, Salihoglu Y, et al. Malignant germ cell tumors of the ovary: a review of 41 cases and risk factors for recurrence. Eur J Gynaecol Oncol 2008;29:635-7.

30. Gadducci A, Sartori E, Maggino T, Zola P, Landoni F, Fanucchi A, et al. Analysis of failures after negative second-look in patients with advanced ovarian cancer: an Italian multicenter study. Gynecol Oncol. 1998;68:150-5.

31. Matte I, Lane D, Laplante C, Rancourt C, Piche A. Profiling of cytokines in human epithelial ovarian cancer ascites. Am J Cancer Res. 2012;2:566-80.

32. Basu P, De P, Mandal S, Ray K, Biswas J. Study of 'patterns of care' of ovarian cancer patients in a 
specialized cancer institute in Kolkata, Eastern India. Indian J Cancer. 2009;46:28-33.

33. Saini SK, Shrivastava S, Singh Y, Dixit AK, Prasad $\mathrm{SN}$. Epidemiology of epithelial ovarian cancer, a single institution-based study in India. Clin Cancer Investig J. 2016;5:20-4.

34. Mondal SK, Banyopadhyay R, Nag DR, Roychowdhury S, Mondal PK, Sinha SK. Histologic pattern, bilaterality and clinical evaluation of 957 ovarian neoplasms: a 10-year study in a tertiary hospital of eastern India. J Can Res Ther. 2011;7:433-7.
35. Doufekas K, Olaitan A. Clinical epidemiology of epithelial ovarian cancer in the UK. Int J Women's Health, 2014;6:537-45.

Cite this article as: Pradhan $\mathrm{HK}$, Singh $\mathrm{P}$,

Ravikumar MS, Gothwal M. Study of risk factors and tumor markers in ovarian malignancy in western part of Odisha: a prospective observational study. Int J Reprod Contracept Obstet Gynecol 2018;7:1571-8. 